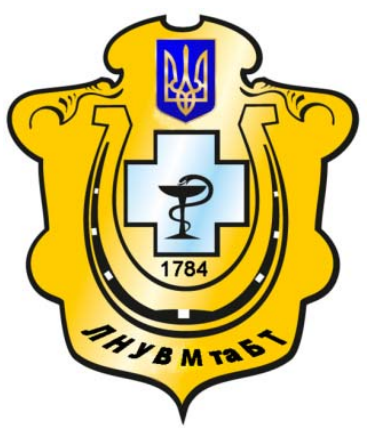

Науковий вісник Львівського національного університету ветеринарної медицини та біотехнологій імені С.3. Гжицького

Scientific Messenger of Lviv National University of Veterinary Medicine and Biotechnologies named after S.Z. Gzhytskyj

doi:10.15421/nvlvet6615

ISSN 2413-5550 print

ISSN 2518-1327 online

$\underline{\text { http://nvlvet.com.ua/ }}$

УДК 619:616-06:616.01/-099:636.7:612.1

\title{
Шок та ДВ3-синдром як патогенетична вісь за бабезіозу собак
}

\author{
О.А. Дубова \\ oxdubova@gmail.com

\begin{abstract}
Житомирський національний агроекологічний університет, вул. Корольова, 39, м. Житомир, 10025, Україна
\end{abstract}

\begin{abstract}
Стаття присвячена дослідженню ускладнень за бабезіозу собак та з'ясуванню їх патогенетичних механізмів. Бабезіоз собак надзвичайно розповсюджений в регіоні Полісся України, оскільки створені ідеальні умови для ензоотичного вогнища. Збудники набувають значної вірулентності, тому захворювання часто супроводжується надзвичайно важкими ускладненнями. У наших дослідженнях установлено, що основну патогенетичну вісь складають шок та синдром дисемінованого внутрішньосудинного згортання крові. Ці обидва процеси є вторинними і створюють «хибне коло», взаємно викликаючи та посилюючи одне одного. Вони виступають визначальними факторами загибелі організму.

Нами було вивчено клінічні ознаки, лабораторні показники та патоморфологічну картину ускладнень за стадіями. Чітко виражені стадії гіперкоагуляиії з ураженням шок-органів, коагулопатії споживання з кровоточивістю на фоні тромбозів, фібринолізу з невгамовними кровотечами і подальшою незворотною термінальною стадією шоку. Основними лабораторними критеріями $\epsilon$ концентрачія продуктів деградачії фібриногена/фібрина та наявність розчинних фібринмономерних комплексів, визначена в етаноловому тесті, а також показник гематокриту. Решта показників і ознак дозволяє ідентифікувати стадію ускладнення.
\end{abstract}

Ключові слова: собаки, бабезіоз, шок, синдром ДВЗ крові, гіперкоагулячія, коагулопатія споживання, фібриноліз, ускладнення, РФМК, ПДФ

\section{Шок и ДВС-синдром как патогенетическая ось при бабезиозе собак}

\author{
О.А. Дубова \\ oxdubova@gmail.com
}

Житомирский национальный агроэкологический университет, ул. Королева, 39, г. Житомир, 10025, Украина

Статья посвящена исследованию осложнений при бабезиозе собак и выяснению их патогенетических механизмов. Бабезиоз собак чрезвычайно распространен в регионе Полесья Украины, поскольку созданы идеальные условия для энзоотического очага. Возбудители приобретают значительную вирулентность, поэтому заболевание часто сопровождается чрезвычайно тяжелыми осложнениями. В наших исследованиях установлено, что основную патогенетическую ось составляют шок и синдром диссеминированного внутрисосудистого свертыввания крови. Эти оба процесса являются вторичныли и создают «порочный круг», взаимно вызывая и усилився друг друга. Они выступают определяющими факторами гибели организма.

Нами были изучены клинические признаки, лабораторные показатели и патологоморфологическая картина осложнений по стадіям. Четко выражены стадии гиперкоагуляции с поражением шок-органов, коагулопатии потребления с кровоточивостью на фоне тромбозов, фибринолиза с непрекращзающимися кровотечениями и дальнейшей необратимой терминальной стадией шока. Основными лабораторными критериями являются конщентрация продуктов деградации фибриногена/фибрина и наличие растворимых фибрин-мономерных комплексов, определенное в этаноловом тесте, а также показатель гематокрита. Остальные показатели и признаки позволяют идентифицировать стадию осложнения.

Ключевые слова: собаки, бабезиоз, шок, синдром ДВС крови, гиперкоагулящия, коагулопатия потребления, фибринолиз, осложнения, РФМК, ПДФ.

\section{Citation:}

Dubova O.A. (2016). Shock and DIC-syndrome as a pathogenetic axis of dogs babesiosis. Scientific Messenger LNUVMBT named after S.Z. Gzhytskyj, 18, 2(66), 70-73. 


\title{
Shock and DIC-syndrome as a pathogenetic axis of dogs babesiosis
}

\author{
O.A. Dubova \\ oxdubova@gmail.com \\ Zhytomyr National Agroecological University, \\ Korolova Str., 39, Zhytomyr, 10025, Ukraine
}

The article is devoted to research of complication of dogs babesiosis and the elucidation of their pathogenetic mechanisms. Babesiosis of dogs is extremely common in Polissya region of Ukraine, as created ideal conditions for enzootic focus. Agents have considerable virulence, so the disease is often accompanied by extremely severe complications. In our researches it is established that the main pathogenetic axis represent the shock and syndrome of disseminated intravascular coagulation of blood. These two processes are the secondary and create a "vicious circle" mutually causing and utilise each other. They are the determining factors of the death of the body.

We studied clinical signs, laboratory indicators and pathological and morphological picture of complication. Clearly the stage of hypercoagulability with the defeat of the shock bodies, of consumption coagulopathy with bleeding on the background of thrombosis, fibrinolysis with ongoing bleeding and further irreversible terminal stage of shock. The main involving laboratory criteria are the concentration of degradation products of fibrinogen/fibrin and the presence of soluble fibrin-monomer complexes defined in the ethanol test, and hematocrit. Other indicators and signs allow you to identify the stage of complications.

Thus, when dogs babesiosis main complications are disseminated intravascular coagulation and shock that affect the vital organs and systems and they are the main determining cause of death of animals.

Key words: dog, babesiosis, shock, DIC blood, hypercoagulation, consumption coagulopathy, fibrinolysis, complications, SFMC, $P D F$.

\section{Вступ}

Бабезіоз собак - надзвичайно розповсюджений протозооз, особливо в зоні Полісся України. Відомо, що збудниками є ендоглобулярні споровики Babesia canis та B. gibsoni, що уражують еритроцити і $\epsilon$ пусковим механізмом розвитку надзвичайно важких пошкоджень життєво важливих органів, які врешті решт приводять до загибелі організму.

Найважливішими ускладненням за впливу високо вірулентного збудника виступає розвиток шоку. На думку дослідників (Mazurkevich and Baganenko, 2004; Vereschagin et al., 2006; Grinev, 2007), шок сам по собі не $є$ діагнозом, а лише «біологічний стан найвищої важкості, наслідки будь-якої визначеної етіології, ... тривалий патологічний прояв системного масштабу, який виникає за умов перевищення шокового порогу первинними ураженнями за силою або часом впливу». За усіх типів шоку, яким би не був початковий механізм його виникнення, загальним кінцевим наслідком, ймовірно, $\epsilon$ «невідповідна перфузія тканин» (Vereschagin et al., 2006), яка негайно відображається на невідповідному клітинному метаболізмі. Дослідники (Barkagan, 1992; Mazurkevich and Baganenko, 2004; Grinev, 2007) вважають, що стан шоку завжди супроводжується мікроциркуляторними та коагулопатичними розладами, визначаючи гемостазіопатію - синдром дисемінованого внутрішньосудинного згортання крові (ДВЗ), що є невід'ємною ланкою «хибного кола» шоку. Саме означений синдром $є$ однією з основних причин смерті при патологічних станах, які супроводжуються розвитком шокових явищ. Він $\epsilon$ морфологічним еквівалентом шоку (Mazurkevich and Baganenko, 2004; Maslyakova, 2005; Mamot and Mamayev, 2008). Таким чином, боротьба з розвитком синдрому ДВЗ крові повинна проводитись негайно (Litvinov, 2000; Maslyakova, 2005; Mamot and Mamayev, 2008).
Враховуючи небезпеку шокового стану для життєдіяльності організму, його своєчасна індикація є життєво необхідною. Отже, з'ясування патогенетичних особливостей розвитку ускладнень за бабезіозу собак дозволить планувати протокол лікування тварини комплексними методами.

Метою нашої роботи є вивчення клінічних ознак, лабораторних показників за розвитку шоку як ускладнення бабезіозу та патологоанатомічної картини.

\section{Матеріал і методи досліджень}

Матеріалом дослідження були 24 собаки, хворі на бабезіоз з ускладненнями 3 боку життєво важливих органів. У 5 тварин спостерігали бурхливий розвиток процесу з летальним кінцем.

Проводили клінічні дослідження тварин, гематологічні (гематокритна величина, концентрація гемоглобіну, кількість формених елементів крові) загальноприйнятими методами. Стан системи гемостазу оцінювали за показниками гемостазіологічних тестів (спонтанне згортання крові, сіліконовий час, протромбінів час, тромбіновий час, визначення спонтанної агрегації еритроцитів та тромбоцитів, етанолів тест, визначення вмісту фібриногену, продуктів деградації фібриногена/фібрина (ПДФ) (Baluda et al., 1980).

Статистичну обробку отриманих даних проводили за допомогою електронних таблиць MS Excel 2013. Вірогідність різниці показників оцінювали за $\mathrm{t}$ критерієм Ст’юдента на 5\% довірчому рівні.

\section{Результати та їх обговорення}

Хворі на бабезіоз собаки найчастіше мали такі клінічні ознаки: лихоманка фебрильного та піретичного типу, відсутність апетиту, загальне пригнічення, анемічність та згодом жовтушнісь слизових оболонок, блювота, інколи жовчю, важке жорстке дихання із задишкою видихаючого типу, тахікардія, гемоглобі- 
нурія, у окремих випадках порушення координації рухів та клоніко-тонічні чи тетанічні судоми.

Аналізуючи клінічну картину, ми можемо відмітити розвиток інтоксикації, анемії i, як наслідок, гіпоксії, недостатності легень, нирок, печінки, яка характеризується синдромами «шокової легені» та «шокової нирки». Така недостатність зумовлена відкладанням фібринових мікротромбів та еритроцитарних сладжів у судинах їх мікроциркуляторного русла (Zerbino and Lukasevich, 1989; Barkagan, 1992; Litvinov, 2000), a самі органи визначаються як шок-органи (Zerbino and Lukasevich, 1989; Mazurkevich and Baganenko, 2004). Отже, клінічні ознаки характеризують розвиток синдрому ДВЗ (його стадії гіперкоагуляції) та шоку, який, за встановленою класифікацією, може бути визначених як циркуляторний. На думку 3.С. Баркагана (Barkagan, 1992), синдром ДВ3 та індукований ним шок дуже швидко набувають вторинного бактеріемічного характеру, або стають інфекційно-септичними. Внутрішньосудинне згортання крові є потужним стимулятором септичного процесу (Zerbino and Lukasevich, 1989; Barkagan, 1992), що зумовлене процесами тромбоутворення.

У деяких тварин [n = 7] надалі з'явилися петехіальні та плямисті кровотечі на слизових оболонках, кров'янисті виділення 3 носу, блювота жовчю 3 домішками крові, криваві діареї. При виконанні лікувальних маніпуляцій спостерігали просочення через шкіру крові, що погано згорталася або не згорталася досить тривалий час. Температура тіла при цьому була зниженою і коливалася у межах $36,3 \pm 0,7{ }^{\circ} \mathrm{C}$. Такі клінічні ознаки притаманні гострій формі стадії коагулопатії споживання синдрому ДВЗ. Ця стадія патогенетично зумовлюється блокадою мікроциркуляторного русла фібрином, агрегатами клітин крові і продуктами протеолізу, внаслідок чого відбувається дистрофія капілярів. Тромбоцити, що залишаються в кров'яному руслі, втрачають агрегацій ну здатність внаслідок блокади іiі ПДФ та протеолізу. Судини втрачають ангіотрофічну функцію і стають проникними (Bokarev et al., 1989; Zerbino and Lukasevich, 1989), що і є однією $з$ головних причин нестримної кровоточивості. Шлунково-кишкові кровотечі є невід'ємними супутниками коагулопатії споживання. Дослідники (Маzurkevich and Baganenko, 2004; Vereschagin et al., 2006; Grinev, 2007) визначають за таких процесів тенденцію до незворотності шокового стану і $є$ небезпечними сигналами.

Серед дослідних тварин 5 собак загинули. Перед загибеллю температура тіла знижувалася до 34,2 \pm $0,3^{\circ} \mathrm{C}$. Проявлялося дихання за типом Чейн-Стокса та Куссмауля. Згодом тварини впадали в кому з явищами гіпотермії та зволоження шкіряного покриву. Означені клінічні ознаки відповідають колапсу. Інколи відмічалися епілептиформні напади. Така кома індукована гострою недостатністю наднирників (синдром Уоттерхауза-Фрідриксена) (Zerbino and Lukasevich, 1989; Bokarev et al., 1989).

Лабораторні дослідження крові також зазнавали певних змін у динаміці перебігу ускладнення. Нами було встановлено зниження ефективного об'єму циркулюючої крові (показник гематокриту вдвічі зниже- ний і становить $0,25 \pm 0,03$ л/л). Це є основним маркером шокового стану. Оскільки на стадії гіперкоагуляції синдрому ДВЗ ми не відмічали ані зовнішньої, ані ознак внутрішньої крововтрати, то шок, визначений нами, є циркуляторним. Виходячи з патогенезу (Zerbino and Lukasevich, 1989; Bokarev et al., 1989; Мazurkevich and Baganenko, 2004), плазма крові, а згодом і формені елементи просочуються у інерстиціальний простір, зумовлюючи набряк тканин.

Гематологічні показники свідчать про анемію нормохромного, а згодом гіперхромного типу. Такий характер анемії може бути пов'язаний з внутрішньосудинним гемолізом, який у значній інтенсивності супроводжує шок і синдром ДВЗ та погіршує їх перебіг, включаючись до «хибного кола».

Різке зниження кількості еритроцитів (майже в 4 рази порівняно 3 здоровими тваринами) може бути зумовлене сладжуванням ї у мікроциркуляторному руслі органів.

У коагуляційних тестах присутня спочатку гіперкоагуляція. Діагностичними маркерами синдрому ДВ3 виступають етанолів тест (1 проти 0), що характеризує наявність розчинних фібрин-мономерних комплексів (РФМК) та наявність ПДФ (2,16 \pm 0,9 г/л проти $0,08 \pm 0,02$ г/л). Також у 2,5 рази знижується вміст фібриногену $(0,88 \pm 0,22$ г/л).

Перехідна стадія синдрому ДВ3 (коагулопатія споживання) також відмічена діагностичними маркерами (етаноловий тест дорівнює 1, а концентрація ПДФ становить 2,87 $\pm 0,15$ г/л). В коагуляційних тестах спостерігаються різноспрямовані зрушення (подовження часу спонтанного згортання крові, сіліконового та протромбінового часу, часу рекальцифікації плазми, але укороченням тромбінового та активованого тромбопластинового часу). Уміст фібриногену надалі знижується $(0,74 \pm 0,2$ г/л). Спонтанна агрегація еритроцитів та тромбоцитів знижується. Судинні стінки не здатні чинити перепони кровотечам. Фактори згортання крові «споживаються» тромбоцитарними тромбами, а фібринолітична система активується (Bokarev et al., 1989). Ця стадія синдрому ДВ3 супроводжує початок термінальної незворотної стадії шоку.

Стадія фібринолізу синдрому ДВЗ характеризується відсутністю згортання крові майже в усіх коагуляцій них тестах, тромбоцитопенією (кількість тромбоцитів становить $87 \pm 18$ Г/л, що втричі нижче фізіологічних показників), еритроцитопенією, гіпофібриногенемією $(0,43 \pm 0,05$ г/л). Етаноловий тест стає сумнівним, а концентрація ПДФ знижується і складає 1,3 $\pm 0,3$ г/л). Кров стає «лаковою». Система гемостазу виснажена. Має місце незворотній геморагічний шок.

Отже, етіологічний фактор, тобто збудник бабезіозу, викликає явища первинного шоку, який потенціює синдром ДВЗ, що є потужним стимулятором вторинного шоку, викликаного розвитком гіперкоагуляції 3 наступною гіпокоагуляцією. Вторинний шок посилює синдром ДВЗ. Виникає «хибне коло» розвитку шоку.

Патологоанатомічним розтином було встановлено такі загальні ознаки: кров рідка, «лакова», геморагічний діатез, ознаки «шокової легені» - інтерстиційний набряк, застійна гіперемія, локальна геморагічна пневмонія, локальні некрози; тромбоз судин селезінки, 
ознаки печінкової недостатності - гостра застійна гіперемія та крайові некрози, білково-жирове переродження; катарально-геморагічний панкреатит; повнокрів'я та тромбоз судин шлунково-кишкового тракту, геморагічний гастроентероколіт; гідронефроз, пієлонефрит та осередкові крововиливи, кортикальні некрози нирок; обширні крововиливи у кіркову речовину наднирників (ймовірно, причина наднирникової коми - синдром Уоттерхауза-Фрідриксена); набряк мозку, застійна гіперемія судин мозкових оболонок та крапчасті крововиливи.

Отже, описані патоморфологічні ознаки характерні для синдрому ДВЗ - трамбування судин життєво важливих органів, геморагічний діатез та не згортання крові. Така картина є головним патоморфологічним критерієм шоку (Mazurkevich and Baganenko, 2004; Vereschagin et al., 2006).

\section{Висновки}

1. Шок та синдром ДВ3 - загально патологічні процеси, що ускладнюють перебіг бабезіозу собак, катастрофічні наслідки яких приводять до загибелі тварин.

2. Первинний шок, спровокований вірулентністю збудника, викликає синдром ДВЗ, який в свою чергу посилює шоковий стан, включаючись, таким чином, у «хибне коло».

3. Клінічні ознаки шоку відповідають клінічним ознакам синдрому ДВ3 і його стадіям, що підтверджується лабораторно і патоморфологічно.

Перспективи подальших досліджень полягають в удосконаленні методів експрес-діагностики ускладнень у вигляді шоку та синдрому ДВ3, які можна проводити терміново під час першого обстеження хворої тварини, а також розробці схем лікування хворих на бабезіоз тварин з включенням засобів, що запобігають розвитку ускладнень.

\section{Бібліографічні посилання}

Baluda, V.P., Barkagan, Z.S., Golgberg, E.D. (1980). Laboratornie metodi issledovaniya sistemi gemostaza. Tomsk, 124-127 (in Russian).

Barkagan, Z.S. (1992). Uzlovie voprosi kompleksnoi terapii ostrogo i podostrogo DVS-sindroma // Vestnik intensivnoy terapii. 1, 11-16 (in Russian).

Bokarev, I.N., Schepotin, B.M., Ena, Ya.M. (1989). Vnutrisosudistoye svertivanie krovi. K.: Zdorovya (in Russian).

Vereschagin, E.I., Vasilyev, S.V., Shabalin, A.V., Vereschagin, G.N. (2006). Tsirkulatornyi shok: sovremennoe predstavlenie, klassifikatsia, terapia: Rukvo dlya vrachey. Novosibirsk (in Russian).

Grinev, M.V. (2007). Shok kak universalniy patogeneticheskiy process pri kriticheskih sostoyaniyah organizma. Vestnik hirurgii im. I.I.Grekova. 166(4), 9297.

Zerbino, D.D., Lukasevich, L.L. (1989). Disseminirovannoe vnutrisosudistoye svertivanie krovi: Fakti i koncepcii. M.: Medicina (in Russian).

Litvinov, R.I. (2000). Klinicheskiye I patomorfologicheskiye aspekti disseminirovannogo vnutrisosudistogo svertivaniya krovi. Kazanskiy medicinskiy zhurnal. 1, 48-52 (in Russian).

Mamot, A.P., Mamayev, A.N. (2008). Sovremennie aspekti patogeneza, diagnostiki I terapii DVSsindroma. Klinicheskaya onkogematologia. 1(1), 6367 (in Russian).

Maslyakova G.N. (2005). O suschnosti I znachenii disseminirovannogo vnutrisosudistogo svertivaniya krovi v patologii. Tromboz, gemostaz I reologia. 1, 8-13 (in Russian).

Mazurkevich, G.S., Baganenko, S.F. (2004). Shok, teoriya, klinika, organizacia protivoshokovoy terapii. $\mathrm{SPb}$ : Politehnika (in Russian).

Стаття надійшла до редакиії 28.09.2016 